\begin{tabular}{c} 
Brazilian Journal \\
of Chemical \\
Engineering \\
\hline
\end{tabular}

ISSN 0104-6632

Printed in Brazil

www.abeq.org.br/bjche

Vol. 28, No. 03, pp. 393 - 402, July - September, 2011

\title{
PHOTOCATALYTIC DISCOLORATION OF REACTIVE BLUE 5G DYE IN THE PRESENCE OF MIXED OXIDES AND WITH THE ADDITION OF IRON AND SILVER
}

\author{
M. C. P. Souza ${ }^{1}$, G. G Lenzi ${ }^{1 *}$, L. M. S. Colpini ${ }^{2}$, L. M. M. Jorge ${ }^{1}$ and O. A. A. Santos ${ }^{1}$ \\ ${ }^{1}$ Universidade Estadual de Maringá, Departamento de Engenharia Química, \\ Phone: + (55) (44) 3011-4770, Fax: + (55) (44) 3011-4792, \\ Av. Colombo 5790, CEP: 87020-900, Maringá - PR, Brazil. \\ E-mail: gianegoncalves@hotmail.com \\ ${ }^{2}$ Universidade Federal do Paraná, Campus Palotina, \\ Curso Superior de Tecnologia em Biocombustíveis, Rua Pioneiro 2153, \\ Jardim Dallas, CEP: 85950-000, Palotina - PR, Brazil.
}

(Submitted: December 12, 2010 ; Revised: May 18, 2011 ; Accepted: May 18, 2011)

\begin{abstract}
This work reports the use of cerium-titania-alumina-based systems modified with Ag and Fe by the wetness impregnation method for the discoloration of blue $5 \mathrm{G}$ dye. The techniques employed to characterize the photocatalysts were: temperature-programmed reduction (TPR), X-ray diffraction (XRD), specific surface area, average pore volume, and average pore diameter. The characterization results indicated that the photocatalysts had different crystalline structures and textural properties. Discoloration with the mixed oxide photocatalyst $\mathrm{CeO}_{2}-\mathrm{TiO}_{2}-\mathrm{Al}_{2} \mathrm{O}_{3}$ gave a result similar to that of $\mathrm{TiO}_{2}$. On the other hand, the addition of $\mathrm{Ag}$ and $\mathrm{Fe}$ to the mixed oxide increased the discoloration and reaction rates of reactive blue $5 \mathrm{G}$ dyes.

Keywords: $\mathrm{CeO}_{2}-\mathrm{TiO}_{2}-\mathrm{Al}_{2} \mathrm{O}_{3}$ mixed oxides; Discoloration; $\mathrm{Fe}-\mathrm{CeO}_{2}-\mathrm{TiO}_{2}-\mathrm{Al}_{2} \mathrm{O}_{3} ; \mathrm{Ag}-\mathrm{CeO}_{2}-\mathrm{TiO}_{2}-\mathrm{Al}_{2} \mathrm{O}_{3}$; Reactive blue $5 \mathrm{G}$ dye; Characterization.
\end{abstract}

\section{INTRODUCTION}

Textile dyes and other industrial dyes are crucial organic compounds that cause an increase in environmental damage. From about $1 \%$ to $20 \%$ of the world's dye production is wasted during the dyeing processes and released in textile effluents (Konstantinou and Albanis, 2004; Zollinger, 1991; Weber and Stickney, 1993; Ràfols and Barceló, 1997; Houas et al., 2001). Dyes make up an abundant class of organic compounds characterized by the presence of unsaturated groups (chromophores), such as $-\mathrm{C}=\mathrm{C}-,-\mathrm{N}=\mathrm{N}-$ and $-\mathrm{C} \equiv \mathrm{N}-$, which are responsible for the dye colors, and functional groups responsible for their fixation to fibers, as for example
$-\mathrm{NH}_{2},-\mathrm{OH},-\mathrm{COOH}$ and $-\mathrm{SO}_{3} \mathrm{H}$ (Molinari et. al., 2004). Due to the environmental impact of dyecontaining effluents, new technologies have been researched for their degradation, such as heterogeneous photocatalysis, which belongs to the category of advanced oxidation processes (AOP) (Özkan et al., 2004; Colpini et al., 2008; Pelegrini et al., 1999; Peralta-Zamora et al., 2003). Titania is a material with attractive applications in photocatalysis. However, $\mathrm{TiO}_{2}$ has band gaps of approximately $3.0-3.2 \mathrm{eV}$. The photocatalytic process must be induced by UV light irradiation. The extremely low surface coverage of organic pollutants on the catalyst $\mathrm{TiO}_{2}$ is the key factor in its low photocatalytic efficiency (Chen and Ray, 1999).

*To whom correspondence should be addressed 
Thus, recent studies have focused on the modification of $\mathrm{TiO}_{2}$ (Yan et al., 2006). In order to investigate this further, mixed oxide $\left(\mathrm{CeO}_{2}-\mathrm{TiO}_{2}\right.$ $\gamma \mathrm{Al}_{2} \mathrm{O}$ ) modified with $\mathrm{Ag}$ and $\mathrm{Fe}$ was prepared and characterized for the discoloration of blue $5 \mathrm{G}$ dye (Figure 1).

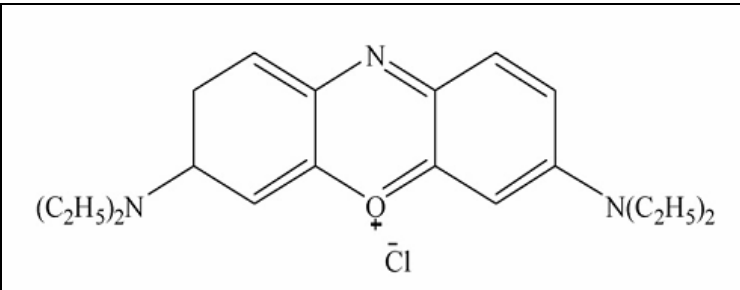

Figure 1: Structure of Maxilon Blue 5G.

\section{EXPERIMENTAL}

\section{Chemicals}

The following chemicals were used as received for the catalyst preparation: i) aluminum oxide $\mathrm{Al}_{2} \mathrm{O}_{3}$ (supplied by Aldrich Sigma with over $99.9 \%$ purity); ii) titanium dioxide $\mathrm{TiO}_{2}$ (supplied by Aldrich with over $99.9 \%$ purity) used as a catalyst precursor; iii) cerium $\mathrm{CeO}_{2}$ IV (supplied by Acros Organics with over 99.9\%); iv) iron(II) sulfate heptahydrate $\mathrm{FeSO}_{4} .7 \mathrm{H}_{2} \mathrm{O}$ (supplied by Synth with over $99.9 \%$ purity); v) silver nitrate $\mathrm{AgNO}_{3}$ (supplied by Synth with over $99.9 \%$ purity).

\section{Catalyst Preparation}

To prepare the catalysts $8.8 \% \mathrm{Ag} / \mathrm{CeO}_{2}-\mathrm{TiO}_{2}$ $\mathrm{Al}_{2} \mathrm{O}_{3}$ and $8.6 \% \mathrm{Fe} / \mathrm{CeO}_{2}-\mathrm{TiO}_{2}-\mathrm{Al}_{2} \mathrm{O}_{3}$ by successive impregnation, the following methodology was used:

After calcining $5 \times 10^{-3} \mathrm{~kg}$ of $\gamma$-alumina at $473.15 \mathrm{~K}$ for 7200 s under a static air atmosphere, it was wetted with distilled water $\left(5 \times 10^{-6} \mathrm{~m}^{3}\right)$ at room temperature and titanium dioxide $\left(5 \times 10^{-3} \mathrm{~kg}\right)$ was added. The solution was stirred at room temperature for $43200 \mathrm{~s}$ for complete homogenization. It was then dried in an oven at $373.15 \mathrm{~K}$ for $43200 \mathrm{~s}$ and calcined at $473.15 \mathrm{~K}$ for 10800 s under a static air atmosphere. The same procedure was used for cerium oxide $\left(5 \times 10^{-3} \mathrm{~kg}\right)$. To the resulting sample, $7 \times 10^{-6} \mathrm{~m}^{3}$ of distilled water and the metallic precursor were added (for the $8.8 \%$ $\mathrm{Ag} / \mathrm{CeO}_{2}-\mathrm{TiO}_{2}-\mathrm{Al}_{2} \mathrm{O}_{3}$ catalyst, $2.5 \times 10^{-3} \mathrm{~kg} \mathrm{AgNO}_{3}$ was added and for $8.6 \% \mathrm{Fe} / \mathrm{CeO}_{2}-\mathrm{TiO}_{2}-\mathrm{Al}_{2} \mathrm{O}_{3}$ catalyst, $5 \times 10^{-3} \mathrm{~kg} \mathrm{FeSO}{ }_{4} \cdot 7 \mathrm{H}_{2} \mathrm{O}$ was added) and then stirred at room temperature for $43200 \mathrm{~s}$. Finally, the catalyst was dried in an oven at $373.15 \mathrm{~K}$ for $43200 \mathrm{~s}$ and calcined at $473.15 \mathrm{~K}$ and $623.15 \mathrm{~K}$ for $10800 \mathrm{~s}$ under a static air atmosphere. For more details, see Souza (2009).

\section{Characterization}

The characterization techniques used in this study were specific surface area, average pore diameter, pore volume, temperature programmed reduction, thermogravimetric analysis, and X-ray diffraction.

\section{Pore Properties (B.E.T. Method)}

The pore properties, such as specific surface area, average pore diameter, and pore volume, were determined with a QUANTACHROME Analyzer Model Nova-1200, using $\mathrm{N}_{2}$ adsorption at $77 \mathrm{~K}$. These analyses were carried out for calcined and non-calcined samples. Before analysis, the samples were submitted to thermal treatment at $573 \mathrm{~K}$ under vacuum for $7200 \mathrm{~s}$ to eliminate any water existing within the pores of the solids.

\section{Temperature Programmed Reduction (TPR)}

The measurements were conducted in a homebuilt TPR apparatus using a quartz tube packed with the catalyst sample inside. The samples $\left(65 \times 10^{-6} \mathrm{~kg}\right)$ were heated from room temperature to $1273.15 \mathrm{~K}$ at a heating rate of $4.72 \mathrm{~K} / \mathrm{s}$ in a $1.75 \% \mathrm{H}_{2} / 98.25 \% \mathrm{Ar}$ gas flow at the rate of $5.0 \times 10^{-7} \mathrm{~m}^{3} / \mathrm{s}$. The thermocouple was located in the central position of the bed and the results were obtained from the hydrogen consumption, which was recorded by a thermal conductivity detector.

\section{X-Ray Diffraction}

The samples were measured in a Rigaku-Denki Diffractometer with $\mathrm{Cu}-\mathrm{K}_{\alpha}$ radiation $(\lambda=1.5406 \AA)$ at a voltage of $140 \mathrm{~V}$ and a current of $40 \mathrm{~mA}$. The patterns obtained were then compared with the diffraction dataset cards from the Joint Committee of Powder Diffraction Standards (JCPDS, 1997).

\section{Photocatalytic Reaction}

\section{Photocatalysis}

The reaction mixture was kept in a reactor consisting of a cylindrical Pyrex cell of $5.0 \times 10^{-4} \mathrm{~m}^{3}$. The tests were performed in $3600 \mathrm{~s}$. The solution with $70 \mathrm{ppm}$ of reactive blue $5 \mathrm{G}$ dye in the presence of $1 \mathrm{~g}$ of the photocatalyst $\left(2 \mathrm{~kg} \cdot \mathrm{m}^{-3}\right)$ was open to the air and an oxygen stream was bubbled into the 
suspension at $8.3 \times 10^{-9} \mathrm{~m}^{3} \cdot \mathrm{s}^{-1}$. A $125 \mathrm{~W}$ medium pressure mercury lamp, surrounded by a quartz thimble, was used for irradiation. In order to maintain room temperature, the vessel was surrounded by a jacket in which cold water flows. The reactor had a magnetic stirrer to ensure the homogeneity of the reaction mixture. At regular intervals, an aliquot of the suspension was withdrawn and filtered through a $0.45 \mu \mathrm{m}$ Millipore filter. The discoloration of the solutions as a function of time was determined with a Shimadzu UV-1203 UV/Vis spectrophotometer. The color was the main parameter analyzed.

\section{Adsorption Behavior of Dyes and Photolysis}

The adsorption tests were accomplished in the same system, but in the dark, according to Kansal et al. (2007). Experiments without a photocatalyst (i.e., photolysis only) were also carried out (Rezaee et al., 2008).

\section{EXPERIMENTAL RESULTS}

Table 1 shows the specific surface areas of $\mathrm{TiO}_{2}$, $\mathrm{CeO}_{2}, \mathrm{Al}_{2} \mathrm{O}_{3}$ and $\mathrm{CeO}_{2}-\mathrm{TiO}_{2}-\mathrm{Al}_{2} \mathrm{O}_{3}$, as well as of the $\mathrm{Ag}$ - and $\mathrm{Fe}$-doped catalysts before and after calcination $(473.15$ and $623.15 \mathrm{~K})$, respectively. The results of specific volume and mean diameter of pores of $\mathrm{TiO}_{2}$, $\mathrm{CeO}_{2}, \mathrm{Al}_{2} \mathrm{O}_{3}, \mathrm{CeO}_{2}-\mathrm{TiO}_{2}-\mathrm{Al}_{2} \mathrm{O}_{3}$ and of the $\mathrm{Ag}$ - and Fe-doped catalysts before and after calcinations at $473.15 \mathrm{~K}$ and at $623.15 \mathrm{~K}$ (Table 2) are presented. Figures 2, 3 and 4 show the $\mathrm{XRD}$ profiles for $\mathrm{CeO}_{2}$ $\mathrm{TiO}_{2}-\mathrm{Al}_{2} \mathrm{O}_{3}, \mathrm{Fe} / \mathrm{CeO}_{2}-\mathrm{TiO}_{2}-\mathrm{Al}_{2} \mathrm{O}_{3}$ and $\mathrm{Ag} / \mathrm{CeO}_{2}-$ $\mathrm{TiO}_{2}-\mathrm{Al}_{2} \mathrm{O}_{3}$, respectively. Figures 5 and 6 show the temperature-programmed reduction profiles for $\mathrm{CeO}_{2}, \mathrm{TiO}_{2}, \mathrm{Al}_{2} \mathrm{O}_{3}, \quad \mathrm{CeO}_{2}-\mathrm{TiO}_{2}-\mathrm{Al}_{2} \mathrm{O}_{3}, \mathrm{Ag} / \mathrm{CeO}_{2}-$ $\mathrm{TiO}_{2}-\mathrm{Al}_{2} \mathrm{O}_{3}$ and $\mathrm{Fe} / \mathrm{CeO}_{2}-\mathrm{TiO}_{2}-\mathrm{Al}_{2} \mathrm{O}_{3}$ calcined at $473.15 \mathrm{~K}$ and $623.15 \mathrm{~K}$, respectively. Figures 7, 8 and 9 show the results for the adsorption of reactive blue $5 \mathrm{G}$ dye on the catalyst using $\mathrm{CeO}_{2}-\mathrm{TiO}_{2}-\mathrm{Al}_{2} \mathrm{O}_{3}$, $\mathrm{Ag} / \mathrm{CeO}_{2}-\mathrm{TiO}_{2}-\mathrm{Al}_{2} \mathrm{O}_{3}$ and $\mathrm{Fe} / \mathrm{CeO}_{2}-\mathrm{TiO}_{2}-\mathrm{Al}_{2} \mathrm{O}_{3}$ photocatalysts, non-calcined and calcined at $473.15 \mathrm{~K}$ and $623.15 \mathrm{~K}$, respectively. Figures 10,11 and 12 show the discoloration of reactive blue $5 \mathrm{G}$ dyes with the photocatalyst, non-calcined and calcined at $473.15 \mathrm{~K}$ and at $623.15 \mathrm{~K}$, respectively.

\section{DISCUSSION}

The results (Table 1) indicate that the specific surface area of non-calcined materials follows the sequence $\mathrm{Al}_{2} \mathrm{O}_{3}>\mathrm{CeO}_{2}>\mathrm{TiO}_{2}$. When these three oxides are combined, the specific surface area is $8.0 \times 10^{3} \mathrm{~m}^{2} / \mathrm{kg}$, which is the same as that observed for $\mathrm{CeO}_{2}$. With the addition of $\mathrm{Ag}$, the surface area decreased, possibly due to pore blocking by the metal.

The surface area obtained for the catalyst containing $\mathrm{Fe}\left(4.7 \times 10^{3} \mathrm{~m}^{2} / \mathrm{kg}\right)$ is smaller than for $\operatorname{Ag}\left(5.3 \times 10^{3} \mathrm{~m}^{2} / \mathrm{kg}\right)$.

When the sample was calcined at $473.15 \mathrm{~K}, \mathrm{TiO}_{2}$ presented an increase in specific surface area and external surface area, as compared with the noncalcined samples. For $\mathrm{Al}_{2} \mathrm{O}_{3}$ and $\mathrm{Fe} / \mathrm{CeO}_{2}-\mathrm{TiO}_{2}-$ $\mathrm{Al}_{2} \mathrm{O}_{3}$, this difference is of the same order of magnitude as the experimental error. On the other hand, a decrease in the micropore surface area occurs. This is possibly due to the removal of volatile contaminants (Lenzi et al., 2008), which favors an increase in the surface area, provoking sinterization of the catalyst particles and decreasing the micropore surface area.

For $\mathrm{CeO}_{2}$ and $\mathrm{Ag} / \mathrm{CeO}_{2}-\mathrm{TiO}_{2}-\mathrm{Al}_{2} \mathrm{O}_{3}$, the specific surface area, external surface area and microspore area decreased, suggesting that some micropores form larger pores and contribute to the decrease in the specific surface area.

For the $\mathrm{CeO}_{2}-\mathrm{TiO}_{2}-\mathrm{Al}_{2} \mathrm{O}_{3}$ catalyst, a decrease in the specific surface area and external surface area occurs. However, the micropore surface area increased due to the crystalline structure change produced by the thermal treatment. The results indicated a change in the specific surface after the thermal treatment (calcinations at $623.15 \mathrm{~K}$ ). Compared with the non-calcined photocatalyst, $\mathrm{TiO}_{2}$ and $\mathrm{Al}_{2} \mathrm{O}_{3}$ presented an increase in the specific surface area and specific external area. However, the specific micropore area decreased due to the removal of volatile contaminants. For the $\mathrm{Fe} / \mathrm{CeO}_{2}-\mathrm{TiO}_{2}-$ $\mathrm{Al}_{2} \mathrm{O}_{3}$ photocatalyst, the specific surface area, external surface area, and micropore surface area were not significantly altered.

For $\mathrm{CeO}_{2}, \mathrm{CeO}_{2}-\mathrm{TiO}_{2}-\mathrm{Al}_{2} \mathrm{O}_{3}$ and $\mathrm{Ag} / \mathrm{CeO}_{2}-\mathrm{TiO}_{2}-$ $\mathrm{Al}_{2} \mathrm{O}_{3}$, the specific surface area and specific external area decreased, and an increase in the micropore surface area occurred due to the crystalline structure change resulting from the thermal treatment.

$\mathrm{TiO}_{2}$ shows high micropore volume (Table 2); however, the mesopore volume of the other oxides $\left(\mathrm{CeO}_{2}, \mathrm{Al}_{2} \mathrm{O}_{3}\right)$ and catalysts $\left(\mathrm{Ag} / \mathrm{CeO}_{2}-\mathrm{TiO}_{2}-\mathrm{Al}_{2} \mathrm{O}_{3}\right.$ $\mathrm{Fe} / \mathrm{CeO}_{2}-\mathrm{TiO}_{2}-\mathrm{Al}_{2} \mathrm{O}_{3}$ ) was larger. The thermal treatment provoked changes in the pore volume and diameter. For $\mathrm{TiO}_{2}$ and $\mathrm{Al}_{2} \mathrm{O}_{3}$, an increase in the total pore volume and mesopore volume occurred, while the micropore volume decreased. The micropore volumes of $\mathrm{TiO}_{2}$ and $\mathrm{Al}_{2} \mathrm{O}_{3}$ are practically the same and the difference is within the experimental error. 
Table 1: Specific surface area of $\mathrm{TiO}_{2}, \mathrm{CeO}_{2}, \mathrm{Al}_{2} \mathrm{O}_{3}, \mathrm{CeO}_{2}-\mathrm{TiO}_{2}-\mathrm{Al}_{2} \mathrm{O}_{3}, \mathrm{Ag} / \mathrm{CeO}_{2}-\mathrm{TiO}_{2}-\mathrm{Al}_{2} \mathrm{O}_{3}$ and $\mathrm{Fe} / \mathrm{CeO}_{2}-$ $\mathrm{TiO}_{2}-\mathrm{Al}_{2} \mathrm{O}_{3}$ - non-calcined, calcined at $473.15 \mathrm{~K}$, calcined at $623.15 \mathrm{~K}$.

\begin{tabular}{|c|c|c|c|c|c|c|c|c|c|}
\hline \multirow{2}{*}{ Material } & \multicolumn{3}{|c|}{$\begin{array}{c}\text { Total pore volume } \\
\left(\mathrm{m}^{3} / \mathrm{kg}\right)\end{array}$} & \multicolumn{3}{|c|}{$\begin{array}{c}\text { Micropore volume } \\
\left(\mathrm{m}^{3} / \mathrm{kg}\right)\end{array}$} & \multicolumn{3}{|c|}{$\begin{array}{c}\text { Micropore surface area } \\
\left(\mathrm{m}^{2} / \mathrm{kg}\right)\left(10^{3}\right)\end{array}$} \\
\hline & $\begin{array}{c}\text { non- } \\
\text { calcined }\end{array}$ & $\begin{array}{c}473.15 \\
\mathrm{~K}\end{array}$ & $\begin{array}{c}623.15 \\
\mathrm{~K}\end{array}$ & $\begin{array}{c}\text { non- } \\
\text { calcined }\end{array}$ & $\begin{array}{c}473.15 \\
\mathrm{~K}\end{array}$ & $\begin{array}{c}623.15 \\
\mathrm{~K}\end{array}$ & $\begin{array}{c}\text { non- } \\
\text { calcined }\end{array}$ & $\begin{array}{c}473.15 \\
\mathrm{~K}\end{array}$ & $\begin{array}{c}623.15 \\
\mathrm{~K}\end{array}$ \\
\hline $\mathrm{TiO}_{2}$ & 5.4 & 10.5 & 12.0 & 0.5 & 7.5 & 8.0 & 4.9 & 3.0 & 4.0 \\
\hline $\mathrm{CeO}_{2}$ & 8.0 & 3.0 & 6.0 & 6.0 & 2.6 & 3.5 & 2.0 & 0.4 & 2.5 \\
\hline $\mathrm{Al}_{2} \mathrm{O}_{3}$ & 9.0 & 9.1 & 10.0 & 4.5 & 5.7 & 6.0 & 4.5 & 3.4 & 4.0 \\
\hline $\mathrm{CeO}_{2}-\mathrm{TiO}_{2}-\mathrm{Al}_{2} \mathrm{O}_{3}$ & 8.0 & 6.2 & 6.0 & 5.7 & 2.6 & 3.4 & 2.3 & 3.6 & 2.5 \\
\hline $\mathrm{Ag} / \mathrm{CeO}_{2}-\mathrm{TiO}_{2}-\mathrm{Al}_{2} \mathrm{O}_{3}$ & 5.3 & 4.1 & 4.0 & 3.5 & 2.5 & 2.0 & 1.8 & 1.6 & 2.0 \\
\hline $\mathrm{Fe} / \mathrm{CeO}_{2}-\mathrm{TiO}_{2}-\mathrm{Al}_{2} \mathrm{O}_{3}$ & 4.7 & 4.8 & 4.8 & 3.1 & 3.4 & 3.2 & 1.6 & 1.4 & 1.6 \\
\hline
\end{tabular}

Table 2: Specific volume and mean pore diameter of $\mathrm{TiO}_{2}, \mathrm{CeO}_{2}, \mathrm{Al}_{2} \mathrm{O}_{3}, \mathrm{CeO}_{2}-\mathrm{TiO}_{2}-\mathrm{Al}_{2} \mathrm{O}_{3}, \mathrm{Ag} / \mathrm{CeO}_{2}-\mathrm{TiO}_{2}$ $\mathrm{Al}_{2} \mathrm{O}_{3}$ and $\mathrm{Fe} / \mathrm{CeO}_{2}-\mathrm{TiO}_{2}-\mathrm{Al}_{2} \mathrm{O}_{3}$ - non-calcined, calcined at $473.15 \mathrm{~K}$, calcined at $623.15 \mathrm{~K}$.

\begin{tabular}{|c|c|c|c|c|c|c|c|c|c|c|c|c|}
\hline \multirow[t]{2}{*}{ Material } & \multicolumn{3}{|c|}{$\begin{array}{c}\text { Total pore volume } \\
\left(\mathrm{m}^{3} / \mathbf{k g}\right)\end{array}$} & \multicolumn{3}{|c|}{$\begin{array}{c}\text { Micropore volume } \\
\left(\mathrm{m}^{3} / \mathrm{kg}\right)\end{array}$} & \multicolumn{3}{|c|}{$\begin{array}{c}\text { Mesopore volume } \\
\left(\mathrm{m}^{3} / \mathbf{k g}\right)\end{array}$} & \multicolumn{3}{|c|}{$\begin{array}{c}\text { Mean pore diameter } \\
(\AA)\end{array}$} \\
\hline & \begin{tabular}{|c|} 
non- \\
calcined
\end{tabular} \mid & $\begin{array}{c}473.15 \\
\mathrm{~K}\end{array}$ & $\begin{array}{c}623.15 \\
\mathrm{~K}\end{array}$ & \begin{tabular}{|c|} 
non- \\
calcined
\end{tabular} & $\begin{array}{c}473.15 \\
\mathrm{~K}\end{array}$ & $\begin{array}{c}623.15 \\
\mathrm{~K}\end{array}$ & $\begin{array}{c}\text { non- } \\
\text { calcined }\end{array} \mid$ & $\begin{array}{c}473.15 \\
\mathrm{~K}\end{array}$ & $\begin{array}{c}623.15 \\
\mathrm{~K}\end{array}$ & $\begin{array}{c}\text { non- } \\
\text { calcined }\end{array}$ & $\begin{array}{c}473.15 \\
\mathrm{~K}\end{array}$ & $\begin{array}{c}623.15 \\
\mathrm{~K}\end{array}$ \\
\hline $\mathrm{TiO}_{2}$ & 3.5 & 14.3 & 16.0 & 2.6 & 1.8 & 2.1 & 1.0 & 12.5 & 13.7 & 25 & 50 & 49 \\
\hline $\mathrm{CeO}_{2}$ & 11.0 & 5.8 & 7.4 & 1.0 & 1.0 & 1.3 & 10.0 & 4.8 & 6.0 & 23 & 53 & 25 \\
\hline $\mathrm{Al}_{2} \mathrm{O}_{3}$ & 10.5 & 11.5 & 12.8 & 2.5 & 1.8 & 2.3 & 8.0 & 9.7 & 10.5 & 42 & 45 & 48 \\
\hline $\mathrm{CeO}_{2}-\mathrm{TiO}_{2}-\mathrm{Al}_{2} \mathrm{O}_{3}$ & 10.2 & 7.0 & 7.3 & 1.2 & 2.0 & 1.3 & 10.0 & 5.0 & 6.0 & 51 & 37 & 50 \\
\hline $\mathrm{Ag} / \mathrm{CeO}_{2}-\mathrm{TiO}_{2}-\mathrm{Al}_{2} \mathrm{O}_{3}$ & 7.0 & 5.5 & 4.6 & 1.0 & 0.9 & 1.1 & 6.0 & 4.5 & 3.5 & 47 & 48 & 44 \\
\hline $\mathrm{Fe} / \mathrm{CeO}_{2}-\mathrm{TiO}_{2}-\mathrm{Al}_{2} \mathrm{O}_{3}$ & 6.7 & 6.7 & 6.6 & 0.7 & 0.7 & 0.7 & 6.0 & 6.0 & 5.9 & 49 & 51 & 51 \\
\hline
\end{tabular}

The XRD patterns of the photocatalyst $\mathrm{CeO}_{2}$ $\mathrm{TiO}_{2}-\mathrm{Al}_{2} \mathrm{O}_{3}$ (Fig. 2), non-calcined and calcined $(473.15$ and $623.15 \mathrm{~K})$, indicated the formation of $\mathrm{TiO}_{2}$ anatase, $\mathrm{CeO}_{2}$ cerium oxide, and $\mathrm{Al}_{2} \mathrm{O}_{3}$ corundum. The thermal treatment did not modify the structure of the mixed oxides. The addition of Fe did not alter the crystalline structure of the material (Fig. 3). However, when Ag was added, there appeared four small peaks (Fig. 4) which were attributed to $\mathrm{AgNO}_{3}$, which is possibly due to residual $\mathrm{Ag}$ precursor impregnated in the sample. The XRD results in general indicate essentially crystalline phases for the original $\mathrm{Ce}, \mathrm{Ti}$ and $\mathrm{Al}$ oxides.

The temperature-programmed reduction (TPR) profile obtained for $\mathrm{TiO}_{2}$ (Fig. 5b) and $\mathrm{Al}_{2} \mathrm{O}_{3}$ (Fig. $5 \mathrm{c}$ ) did not show hydrogen consumption or reduction in the peaks. For $\mathrm{CeO}_{2}$ (Fig. 5a), one peak occurred at around 973.15-1273.15 $\mathrm{K}$, indicating the reduction of this material. For the mixed $\mathrm{CeO}_{2}-\mathrm{TiO}_{2}$ $\mathrm{Al}_{2} \mathrm{O}_{3}$ oxides (Fig. 5d), the material presented one peak around $973.15 \mathrm{~K}$, which had a lower intensity than in $\mathrm{CeO}_{2}$, perhaps due to the interaction with the other oxides $\left(\mathrm{Al}_{2} \mathrm{O}_{3}\right.$ and $\left.\mathrm{TiO}_{2}\right)$ and a possibly more difficult reduction. The $\mathrm{Ag} / \mathrm{CeO}_{2}-\mathrm{TiO}_{2}-\mathrm{Al}_{2} \mathrm{O}_{3}$ (Fig. 5e) photocatalyst presented two peaks at a low temperature, around $373.15-523.15 \mathrm{~K}$ and another at a high temperature of $523.15-773.15 \mathrm{~K}$. These peaks indicate the reduction $\mathrm{Ag}^{2+} \rightarrow \mathrm{Ag}^{+} \rightarrow \mathrm{Ag}^{0}$. The $\mathrm{Fe} / \mathrm{CeO}_{2}-\mathrm{TiO}_{2}-\mathrm{Al}_{2} \mathrm{O}_{3}$ (Fig. 5f) material presented one high-intensity peak situated between 703.15 and $993.15 \mathrm{~K}$, which was attributed to the reduction of $\mathrm{Fe}^{3+}$ to $\mathrm{Fe}^{2+}$. The second broad small peak situated at $720-1273.15 \mathrm{~K}$ indicates the reduction $\mathrm{Fe}^{2+} \rightarrow \mathrm{Fe}^{0}$ and then cerium reduction. 


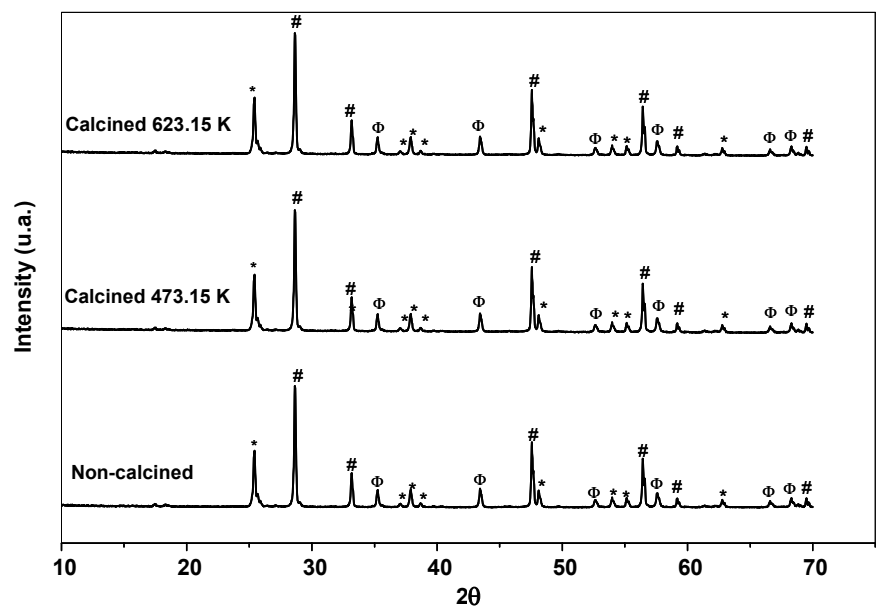

Figure 2: XRD pattern of the $\mathrm{CeO}_{2}-\mathrm{TiO}_{2}-\mathrm{Al}_{2} \mathrm{O}_{3}$ samples, where: (*) $\mathrm{TiO}_{2}$ anatase (JCPDS 21-1272), (\#) $\mathrm{CeO}_{2}$ cerium oxide (JCPDS 78-0694) and ( $\left.\Phi\right) \mathrm{Al}_{2} \mathrm{O}_{3}$ corundum (JCPDS 74-1081).

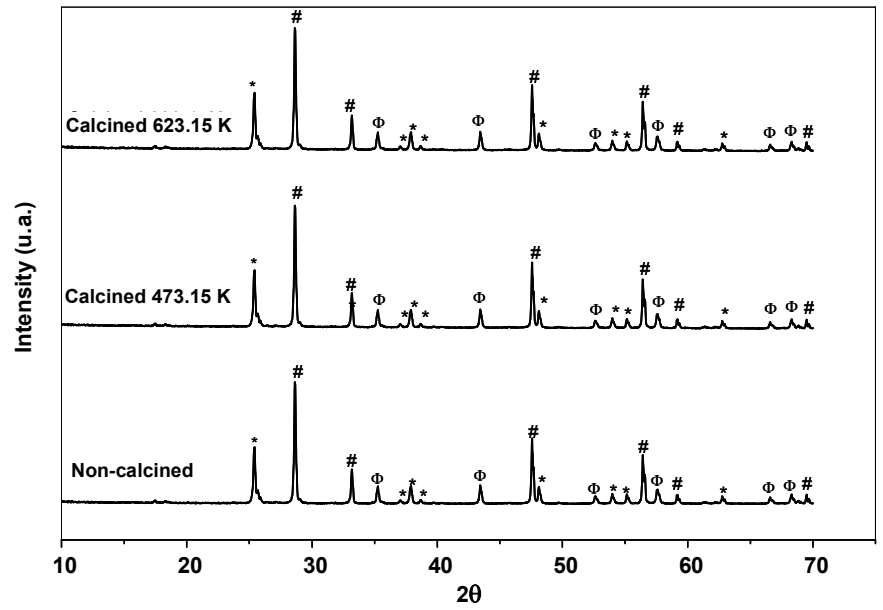

Figure 3: $\mathrm{XRD}$ pattern of the $\mathrm{Fe} / \mathrm{CeO}_{2}-\mathrm{TiO}_{2}-\mathrm{Al}_{2} \mathrm{O}_{3}$ samples, where: (*) $\mathrm{TiO}_{2}$ anatase (JCPDS 21-1272), (\#) $\mathrm{CeO}_{2}$ cerium oxide (JCPDS 78-0694) and $(\Phi) \mathrm{Al}_{2} \mathrm{O}_{3}$ corundum (JCPDS 74-1081).

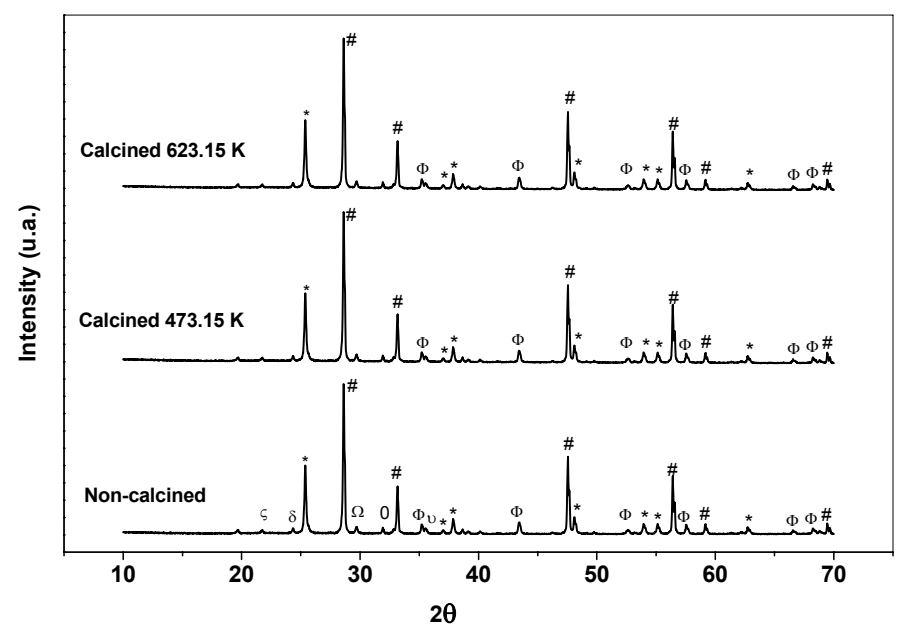

Figure 4: $\mathrm{XRD}$ pattern of the $\mathrm{Ag} / \mathrm{CeO}_{2}-\mathrm{TiO}_{2}-\mathrm{Al}_{2} \mathrm{O}_{3}$ samples, where: (*) $\mathrm{TiO}_{2}$ anatase (JCPDS 21-1272), (\#) $\mathrm{CeO}_{2}$ cerium oxide (JCPDS 78-0694), (Ф) $\mathrm{Al}_{2} \mathrm{O}_{3}$ corundum (JCPDS 74-1081) and ( $\left.\delta\right) \mathrm{AgNO}_{3}$ silver nitrate oxide (JCPDS 01-0856). 


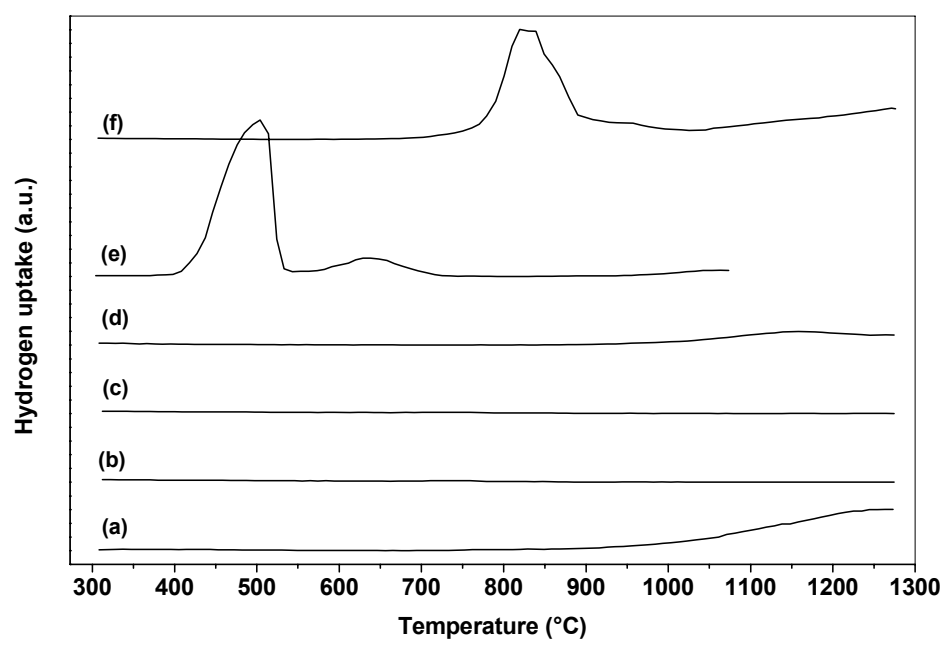

Figure 5: TPR for catalysts calcined at $473.15 \mathrm{~K}$, where: (a) $\mathrm{CeO}_{2}$, (b) $\mathrm{TiO}_{2}$, (c) $\mathrm{Al}_{2} \mathrm{O}_{3}$, (d) $\mathrm{CeO}_{2}-\mathrm{TiO}_{2}-\mathrm{Al}_{2} \mathrm{O}_{3}$, (e) $\mathrm{Ag} / \mathrm{CeO}_{2}-\mathrm{TiO}_{2}-\mathrm{Al}_{2} \mathrm{O}_{3}$ and (f) $\mathrm{Fe} / \mathrm{CeO}_{2}-\mathrm{TiO}_{2}-\mathrm{Al}_{2} \mathrm{O}_{3}$.

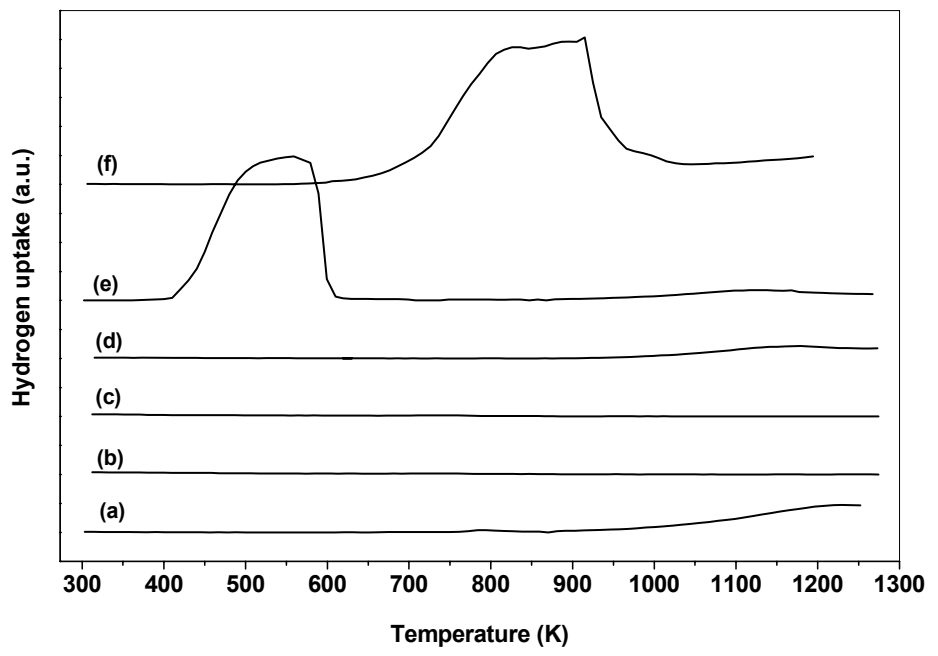

Figure 6: $\mathrm{TPR}$ for catalysts calcined at $623.15 \mathrm{~K}$, where: (a) $\mathrm{CeO}_{2}$, (b) $\mathrm{TiO}_{2}$, (c) $\mathrm{Al}_{2} \mathrm{O}_{3}$, (d) $\mathrm{CeO}_{2}-\mathrm{TiO}_{2}-\mathrm{Al}_{2} \mathrm{O}_{3}$, (e) $\mathrm{Ag} / \mathrm{CeO}_{2}-\mathrm{TiO}_{2}-\mathrm{Al}_{2} \mathrm{O}_{3}$ and (f) $\mathrm{Fe} / \mathrm{CeO}_{2}-\mathrm{TiO}_{2}-\mathrm{Al}_{2} \mathrm{O}_{3}$.

The TPR profiles of $\mathrm{CeO}_{2}, \mathrm{TiO}_{2}, \mathrm{Al}_{2} \mathrm{O}_{3}$ and the $\mathrm{CeO}_{2}-\mathrm{TiO}_{2}-\mathrm{Al}_{2} \mathrm{O}_{3}$ photocatalyst calcined at $623.15 \mathrm{~K}$ (Fig. 6) were similar to those of the materials calcined at $473.15 \mathrm{~K}$. However, the profiles for $\mathrm{Ag} / \mathrm{CeO}_{2}-\mathrm{TiO}_{2}-\mathrm{Al}_{2} \mathrm{O}_{3}$ and $\mathrm{Fe} / \mathrm{CeO}_{2}-\mathrm{TiO}_{2}-\mathrm{Al}_{2} \mathrm{O}_{3}$ show broader peaks, indicating that this may be the result of a larger dispersion of these metals on the catalyst surface (Kansal et al., 2007). For the photocatalyst $\mathrm{Ag} / \mathrm{CeO}_{2}-\mathrm{TiO}_{2}-\mathrm{Al}_{2} \mathrm{O}_{3}$, the reduction $\mathrm{Ag}^{+} \rightarrow \mathrm{Ag}^{0}$ occurs.

The analysis of the adsorption tests (Fig. 7, 8 and 9) indicates that the presence of $\mathrm{Fe}$ favors greater discoloration and that its effect becomes more efficient as the calcination temperature increases, with the largest adsorption being observed for the photocatalyst calcined at $623.15 \mathrm{~K}$.

The $\mathrm{CeO}_{2}-\mathrm{TiO}_{2}-\mathrm{Al}_{2} \mathrm{O}_{3}$ mixed-oxide photocatalysts calcined at 473.15 and $623.15 \mathrm{~K}$ had similar structures and surface areas. However, the photocatalyst calcined at $473.15 \mathrm{~K}$ presented a larger adsorption of reactive blue $5 \mathrm{G}$ dye due to its larger micropore surface area of $3.6 \times 10^{3} \mathrm{~m}^{2} / \mathrm{kg}$ as compared to $2.5 \times 10^{3} \mathrm{~m}^{2} / \mathrm{kg}$ when calcined at $623.15 \mathrm{~K}$.

For $\mathrm{TiO}_{2}, \mathrm{CeO}_{2}-\mathrm{TiO}_{2}-\mathrm{Al}_{2} \mathrm{O}_{3}, \mathrm{Ag} / \mathrm{CeO}_{2}-\mathrm{TiO}_{2}-\mathrm{Al}_{2} \mathrm{O}_{3}$, $\mathrm{Al}_{2} \mathrm{O}_{3}$ and $\mathrm{CeO}_{2}$, the discoloration obtained by adsorption was approximately similar. 


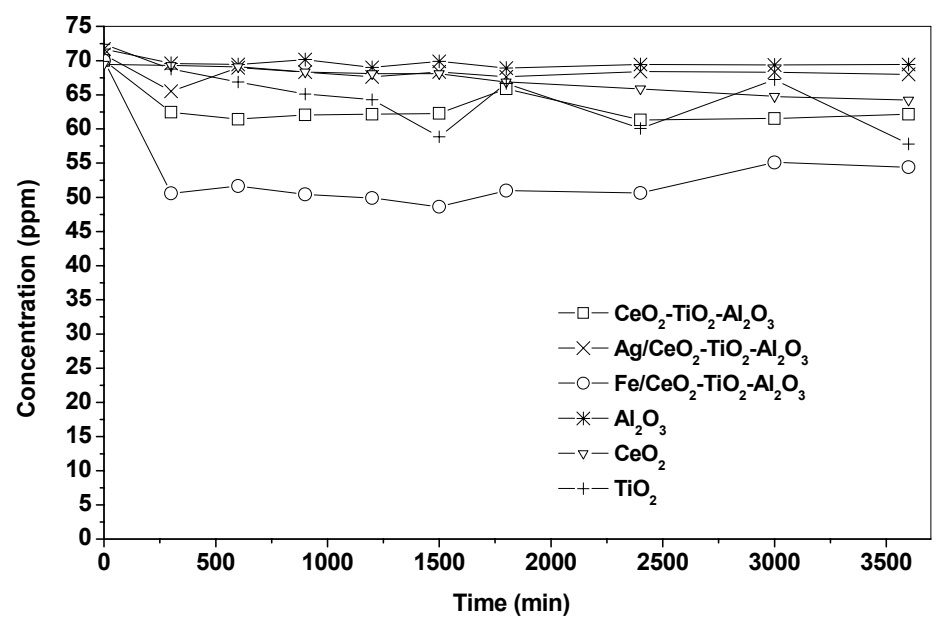

Figure 7: Adsorption of reactive blue 5G dye on non-calcined photocatalysts.

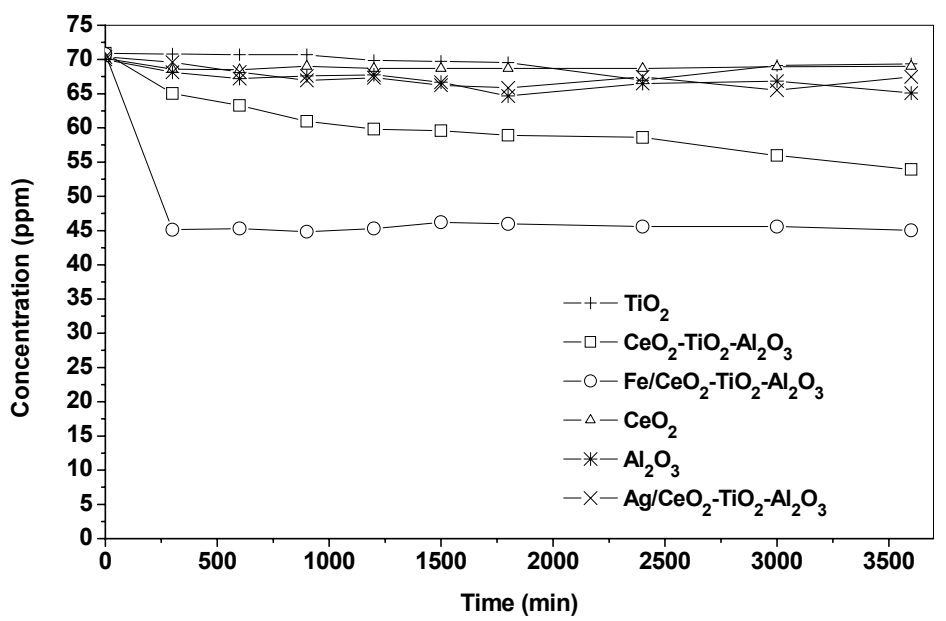

Figure 8: Adsorption of reactive blue 5G dye on photocatalyst calcined at $473.15 \mathrm{~K}$.

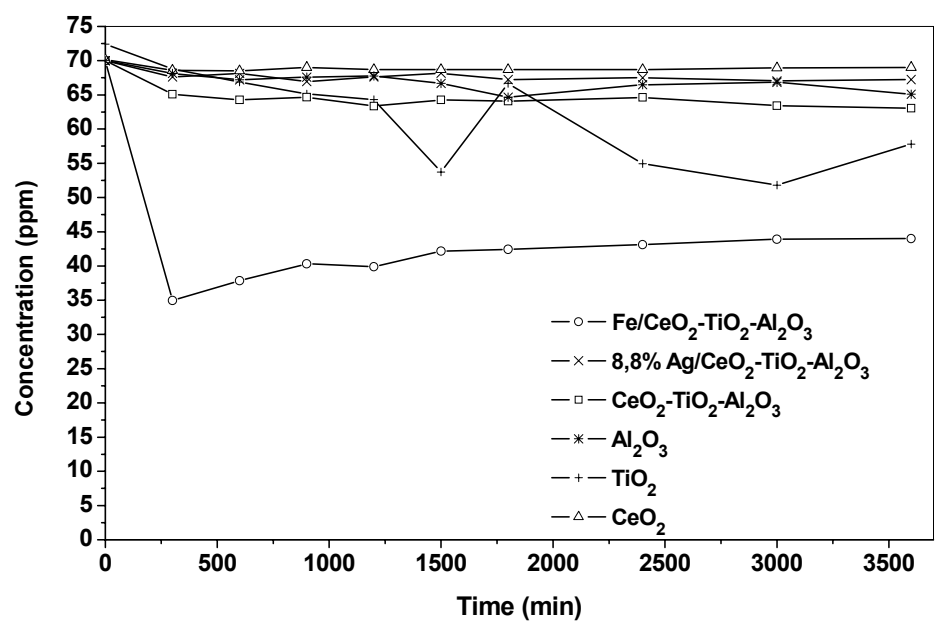

Figure 9: Adsorption of reactive blue 5G dye on photocatalyst calcined at $623.15 \mathrm{~K}$. 
The result for the photolysis test without a catalyst indicated a discoloration of the reactive blue $5 \mathrm{G}$ dye solution of around $8.57 \%$ in $3600 \mathrm{~s}$.

The discoloration occurs quickly under these conditions for the photocatalyzed reactions, as observed in Figs. 10, 11 and 12, except for $\mathrm{Al}_{2} \mathrm{O}_{3}$ and $\mathrm{CeO}_{2}$. However, the discoloration times were different. This can be observed from the values inside the figures, which show the results of the kinetic study of the disappearance of the dyes for an initial concentration of $70 \mathrm{~kg} / \mathrm{m}^{3}$. The values show that the photocatalytic discoloration of dyes in an aqueous solution can be described by a first order kinetic model, $\ln \left(\mathrm{C}_{0} / \mathrm{C}\right)=\mathrm{kt}$, where $\mathrm{C}_{0}$ is the initial concentration and $\mathrm{C}$ is the concentration at any $\mathrm{t}$ time.

The results for the non-calcined photocatalyst (Fig. 10) were better for $\mathrm{Fe} / \mathrm{CeO}_{2}-\mathrm{TiO}_{2}-\mathrm{Al}_{2} \mathrm{O}_{3}$ and $\mathrm{TiO}_{2}$, which discolored $100 \%$ of the solution with 70 $\mathrm{ppm}$ of reactive blue $5 \mathrm{G}$ dye. The time for total discoloration (100\%) was shorter for $\mathrm{Fe} / \mathrm{CeO}_{2}-\mathrm{TiO}_{2}$ $\mathrm{Al}_{2} \mathrm{O}_{3}$ (30 min). $\mathrm{CeO}_{2}, \mathrm{Al}_{2} \mathrm{O}_{3}, \mathrm{CeO}_{2}-\mathrm{TiO}_{2}-\mathrm{Al}_{2} \mathrm{O}_{3}$ and $\mathrm{Ag} / \mathrm{CeO}_{2}-\mathrm{TiO}_{2}-\mathrm{Al}_{2} \mathrm{O}_{3}$ produced $7.8 \%, 21.8 \%, 95.5 \%$ and $99.7 \%$ discoloration, respectively.

Figure 11 shows that the photocatalyst calcined at $473.15 \mathrm{~K}$ produced $100 \%$ discoloration of reactive blue $5 \mathrm{G}$ dye in this order: $\mathrm{Fe} / \mathrm{CeO}_{2}-\mathrm{TiO}_{2}-\mathrm{Al}_{2} \mathrm{O}_{3}>$ $\mathrm{Ag} / \mathrm{CeO}_{2}-\mathrm{TiO}_{2}-\mathrm{Al}_{2} \mathrm{O}_{3}>\mathrm{TiO}_{2}$. The reaction rate was different for each catalyst, and the shortest discoloration time was obtained for $\mathrm{Fe} / \mathrm{CeO}_{2}-\mathrm{TiO}_{2}$ $\mathrm{Al}_{2} \mathrm{O}_{3}$ with an apparent catalyst rate constant of $3.5 \times 10^{-3} \mathrm{~s}^{-1}$. The $\mathrm{CeO}_{2}, \mathrm{Al}_{2} \mathrm{O}_{3}$ and $\mathrm{CeO}_{2}-\mathrm{TiO}_{2}-\mathrm{Al}_{2} \mathrm{O}_{3}$ oxides and mixed oxides produced 15.5, 14.3 and
$96.3 \%$ discoloration, respectively.

Complete discoloration (100\%) (Fig. 12) followed this order: $\mathrm{Fe} / \mathrm{CeO}_{2}-\mathrm{TiO}_{2} \mathrm{Al}_{2} \mathrm{O}_{3}>\mathrm{Ag} / \mathrm{CeO}_{2}$ $\mathrm{TiO}_{2}-\mathrm{Al}_{2} \mathrm{O}_{3}>\mathrm{TiO}_{2}$ for the photocalysts calcined at $623.15 \mathrm{~K} . \mathrm{CeO}_{2}, \mathrm{Al}_{2} \mathrm{O}_{3}$ and $\mathrm{CeO}_{2}-\mathrm{TiO}_{2}-\mathrm{Al}_{2} \mathrm{O}_{3}$ showed discolorations of around 8.2, 21.6 and $96.4 \%$, respectively.

It was observed that the time for discoloration was influenced by thermal treatment; when the calcinations temperature increased, the time of discoloration decreased. The modification of the specific surface area of the photocatalyst may have favored the photocatalytic discoloration under the conditions studied.

It can be observed in Figures 11 and 12 that the mixed oxides produced around $96 \%$ discoloration of reactive blue $5 \mathrm{G}$ dye in $3600 \mathrm{~s}$ of reaction time, while the oxide $\mathrm{TiO}_{2}$ produced $100 \%$. However, with the addition of $\mathrm{Fe}$, the discoloration time decreased to $15 \mathrm{~min}$ for $\mathrm{Fe} / \mathrm{CeO}_{2}-\mathrm{TiO}_{2}-\mathrm{Al}_{2} \mathrm{O}_{3}$ calcined at $473.15 \mathrm{~K}$.

For the photocatalysts $\mathrm{TiO}_{2}, \mathrm{CeO}_{2}-\mathrm{TiO}_{2}-\mathrm{Al}_{2} \mathrm{O}_{3}$, $\mathrm{CeO}_{2}$ and $\mathrm{Al}_{2} \mathrm{O}_{3}$ calcined at different temperatures, no significant changes in discoloration time took place. Non-calcined $\mathrm{Ag} / \mathrm{CeO}_{2}-\mathrm{TiO}_{2}-\mathrm{Al}_{2} \mathrm{O}_{3}$ had similar characteristics (B.E.T. and XRD) after calcination, although the time of discoloration for the photocatalyst calcined at $623.15 \mathrm{~K}$ was shorter, possibly due to the larger elimination of contaminants from the surface of the photocatalyst, which may have favored the reaction. $\mathrm{Fe} / \mathrm{CeO}_{2}-\mathrm{TiO}_{2}-\mathrm{Al}_{2} \mathrm{O}_{3}$ catalysts calcined at 473.15 and $623.15 \mathrm{~K}$ had similar discoloration times.

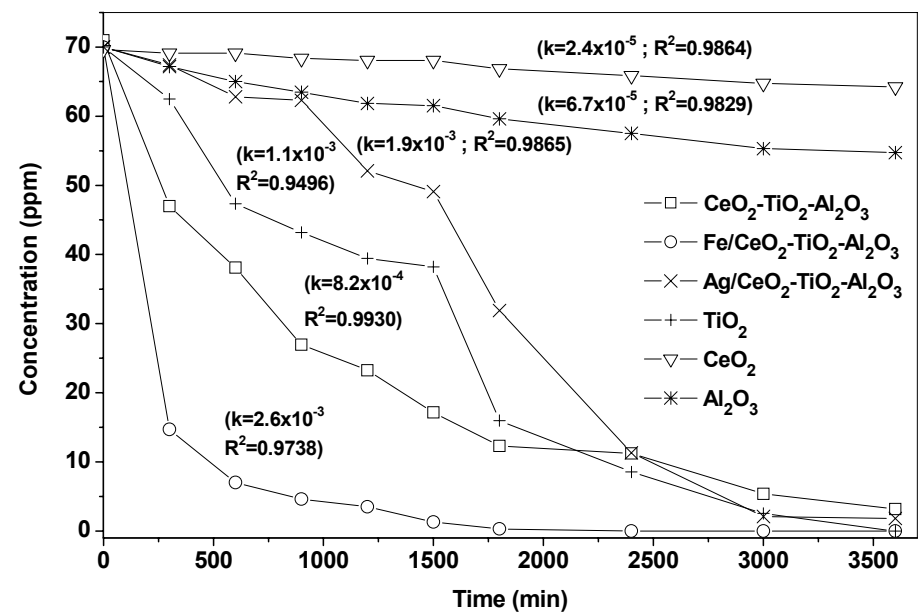

Figure 10: Photocatalytic discoloration of reactive blue $5 \mathrm{G}$ dye with $\mathrm{CeO}_{2}, \mathrm{TiO}_{2}, \mathrm{Al}_{2} \mathrm{O}_{3}$ and $\mathrm{Fe} / \mathrm{CeO}_{2}-\mathrm{TiO}_{2}-\mathrm{Al}_{2} \mathrm{O}_{3}$ non-calcined photocatalysts. 


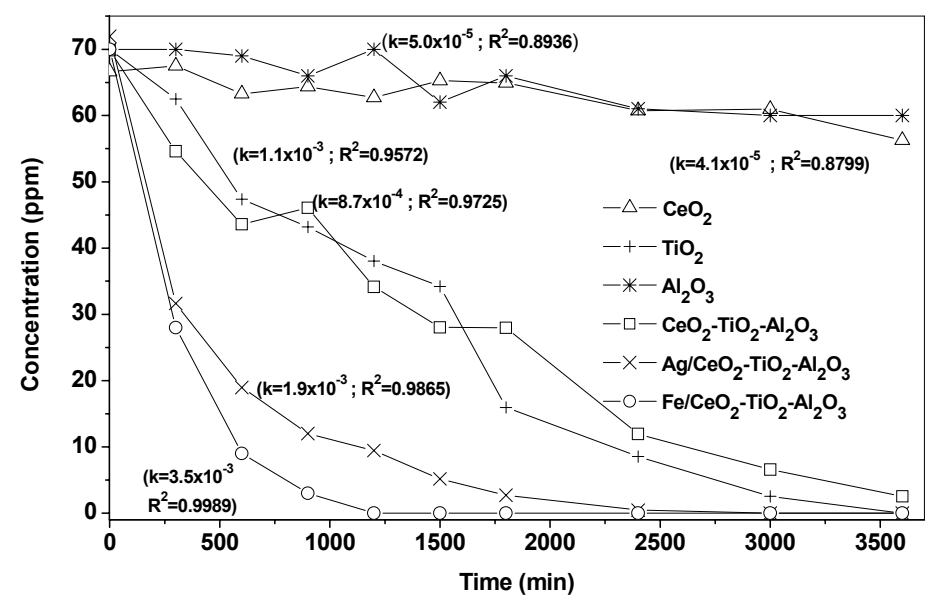

Figure 11: Photocatalytic discoloration of reactive blue 5G dye with $\mathrm{CeO}_{2}, \mathrm{TiO}_{2}, \mathrm{Al}_{2} \mathrm{O}_{3}, \mathrm{CeO}_{2}-$ $\mathrm{TiO}_{2}-\mathrm{Al}_{2} \mathrm{O}_{3}, \mathrm{Ag} / \mathrm{CeO}_{2}-\mathrm{TiO}_{2}-\mathrm{Al}_{2} \mathrm{O}_{3}$ and $\mathrm{Fe} / \mathrm{CeO}_{2}-\mathrm{TiO}_{2}-\mathrm{Al}_{2} \mathrm{O}_{3}$ photocatalysts calcined at $473.15 \mathrm{~K}$.

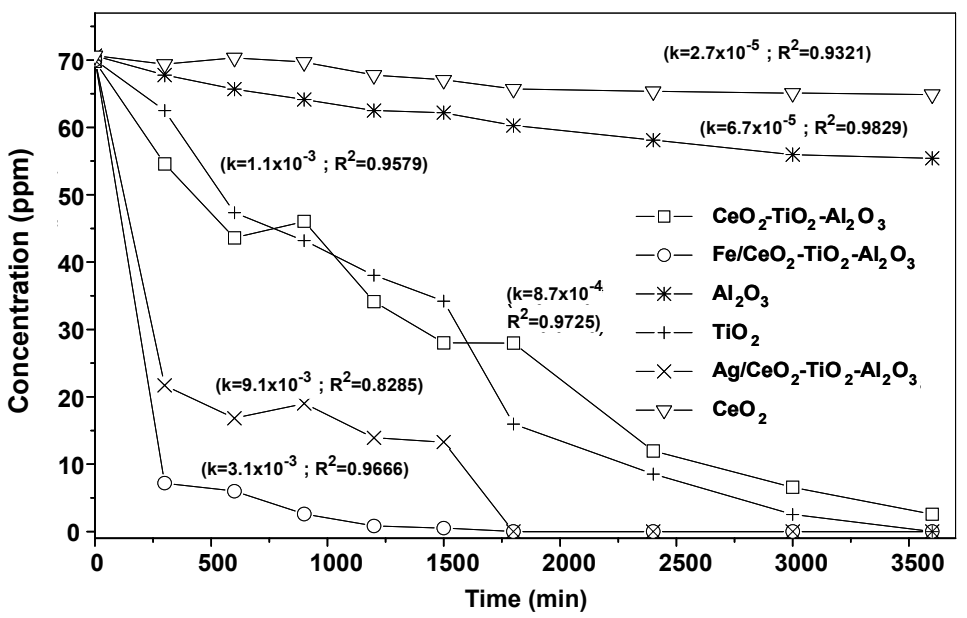

Figure 12: Photocatalytic discoloration of reactive blue $5 \mathrm{G}$ dye with $\mathrm{CeO}_{2}, \mathrm{TiO}_{2}, \mathrm{Al}_{2} \mathrm{O}_{3}, \mathrm{CeO}_{2^{-}}$ $\mathrm{TiO}_{2}-\mathrm{Al}_{2} \mathrm{O}_{3}, \mathrm{Ag} / \mathrm{CeO}_{2}-\mathrm{TiO}_{2}-\mathrm{Al}_{2} \mathrm{O}_{3}$ and $\mathrm{Fe} / \mathrm{CeO}_{2}-\mathrm{TiO}_{2}-\mathrm{Al}_{2} \mathrm{O}_{3}$ photocatalysts calcined at $623.15 \mathrm{~K}$.

\section{CONCLUSIONS}

The obtained catalysts have different characteristic textures. However, a larger specific surface area does not imply better photocatalytic activity. The results indicate that the calcination temperature has an influence on the discoloration of reactive blue $5 \mathrm{G}$ dye. The oxides $\mathrm{CeO}_{2}$ and $\mathrm{Al}_{2} \mathrm{O}_{3}$ showed low catalytic activity. However, the $\mathrm{CeO}_{2}$ $\mathrm{TiO}_{2}-\mathrm{Al}_{2} \mathrm{O}_{3}$ mixed oxide gave results similar to $\mathrm{TiO}_{2}$, with $96 \%$ and $100 \%$ discoloration, respectively, for all the calcination temperatures. The addition of $\mathrm{Fe}$ and $\mathrm{Ag}$ to the mixed oxide increased the rate of discoloration of reactive blue $5 \mathrm{G}$ dye. The only exception was the non-calcined sample $\mathrm{Ag} / \mathrm{CeO}_{2}$ $\mathrm{TiO}_{2}-\mathrm{Al}_{2} \mathrm{O}_{3}$, which presented $97.7 \%$ discoloration.

\section{REFERENCES}

Chen, D.-W., Ray, A. K., Photocatalytic kinetics of phenol and its derivatives over UV irradiated $\mathrm{TiO}_{2}$. Appl. Catal., B: Environ., 23, 143 (1999).

Colpini, L. M. S., Alves, H. J., Santos, O. A. A., Costa, C. M. M., Discoloration and degradation of textile dye aqueous solutions with titanium oxide catalysts obtained by sol-gel method. Dyes and Pigments, 76, 525 (2008). 
Houas, A., Lachheb, H., Ksibi, M., Elaloui, E., Guillard, C., Hermann J. M. Photocatalytic degradation pathway of methylene blue in water. Appl. Catal., B: Environ, 31, 145 (2001).

JCPDS, Internacional Centre for Diffraction Data. PCPDFWIN, 130 (1997).

Kansal, S. K., Singh, M., Sud, D., Studies on photodegradation of two commercial dyes in aqueous phase using different photocatalysts. Journal of Hazardous Materials, 141, 581 (2007).

Konstantinou, I. K., Albanis T. A., TiO2-assisted photocatalytic degradation of zo dyes in aqueous solution: kinetic and mechanistic investigations. A review. Appl. Catal. B: Environ., Amsterdam, 49, 1 (2004).

Lenzi, G. G., Lenzi, M. K., Baesso, M. L., Bento, A. C., Jorge, L. M. M., Santos, O. A. A., Cobalt, nickel and ruthenium-silica based materials synthesized by the sol-gel method. Journal of Non-Crystalline Solids, 354, 4811 (2008).

Molinari, R., Pirillo, F., Falco, M., Loddo, V., Palmisano, L., Photocatalytic degradation of dyes by using a membrane reactor. Chem. Eng. Process, 43, 1103 (2004).

Özkan, A., Özkan, M. H., Gürkan, R., Akcay, M., Sökmen, M., Photocatalytic degradation of a textile azo dyes, Sirius Gelb $\mathrm{GC}$ on $\mathrm{TiO}_{2}$ or $\mathrm{Ag}-\mathrm{TiO}_{2}$ particles in the absence and presence of UV/VIS irradiation: The effects of some inorganic anions on the photocatalysis.
J. Photochem. Photobiol., 163, 29 (2004).

Pelegrini, R., Peralta-Zamora, P., Andrade, A. R., Reyes, J., Duran, N., Electrochemically assisted photocatalytic degradation of reactive dyes. Appl. Catal. B Environ., 22, 83 (1999).

Peralta-Zamora, P., Pereira, C. M., Tiburtius, E. R. L., Moraes, S. G., Rosa, M. A., Minussi, R. C., Durán, N., Decolorization of reactive dyes by immobilized laccase. Appl. Catal. B Environ., 42, 131 (2003).

Ràfols, C., Barceló, D. Determination of mono- and disulphonated azo dyes by liquid chromatographyatmospheric pressure ionization mass spectrometry. J. Chromatogr. A., 777, 177 (1997).

Rezaee, A., Taghi Ghaneian, M., Hashemian, S. J., Moussavi, G., Khavanin, A., Ghanizadeh, G., Decolorization of Reactive Blue 19 Dye from Textile Wastewater by $\mathrm{UV} / \mathrm{H}_{2} \mathrm{O}_{2}$. Process Journal of Applied Sciences, 6, 1108 (2008).

Souza, M. C. P., M. Sc.Thesis (In Portuguese), Universidade Estadual de Maringá (2009).

Weber, J., Stickney, V. C., Hydrolysis kinetics of Reactive Blue 19-vinyl sulfone. Water Res. 27, 63 (1993).

Yan, L., De-Zhi, S., Lin, C., Yan-Ping, L., Preparation and characterization of $\mathrm{Fe}_{2} \mathrm{O}_{3}-\mathrm{Ce}_{2}-\mathrm{TiO}_{2}-\gamma \mathrm{Al}_{2} \mathrm{O}_{3}$ catalyst for degradation dye wastewater. Journal of Environmental Sciences, 18, 189 (2006).

Zollinger, H., Color Chemistry: Synthesis. $2^{\text {nd }}$ Revised Ed., VCH, Wertheimer (1991). 